Marquette University

e-Publications@Marquette

Economics Faculty Research and Publications

Economics, Department of

3-1-2006

Evaluating the Long-run Impacts of the 9/11 Terrorist Attacks on US Domestic Airline Travel

Scott S. Blunk

Marquette University

David E. Clark

Marquette University, david.clark@marquette.edu

James McGibany

Marquette University, james.mcgibany@marquette.edu

Accepted version. Applied Economics, Vol. 38, No. 4 (March 2006): 363-370. DOI. (C) 2006 Taylor \& Francis. Used with permission. 


\title{
Evaluating the Long-Run Impacts of The 9/11 Terrorist Attacks On US Domestic Airline Travel
}

\author{
Scott S. Blunk \\ Department of Economics, Marquette University \\ Milwaukee, WI \\ David E. Clark \\ Department of Economics, Marquette University \\ Milwaukee, WI \\ James M. McGibany \\ Department of Economics, Marquette University \\ Milwaukee, WI
}

\begin{abstract}
Although the US airline industry began 2001 with 24 consecutive profitable quarters, including net profits in 2000 totaling $\$ 7.9$ billion, the impact of the $9 / 11$ event on the industry was substantial. Whereas the recession that began in early 2001 signaled the end of profitability, the 9/11 terrorist attacks pushed the industry into financial crisis after air travel dropped 20\% over the September-December 2001 period compared to the same period in 2000. Given the decline in domestic air travel, an important question is whether the detrimental impact of the attacks was temporary or permanent. That is, did airline travel return to the trend that existed prior to the terrorist attacks? There are theoretical reasons to the believe that it would not. Economists have long viewed travel-mode choices as the outcome of a comparison of opportunity costs and benefits. Thus, anything that permanently raises the opportunity cost of travel, holding benefits constant, should reduce the level of travel volume. To determine whether air travel was permanently reduced, we use econometric and time-series forecasting models

Applied Economics, Vol. 36, No. 4 (March 2006): pg. 363-370. DOI. This article is (C) Taylor \& Francis (Routledge) and permission has been granted for this version to appear in e-Publications@Marquette. Taylor \& Francis (Routledge) does not grant permission for this article to be further copied/distributed or hosted elsewhere without the express permission from Taylor \& Francis (Routledge).
\end{abstract}


to generate a counter-factual forecast of air travel volume in the absence of the terrorist attacks. These dynamic forecasts are compared to actual air travel levels to determine the impact of the terrorist attacks. The findings suggest that domestic air travel did not return to the levels that would have existed in the absence of the attack.

\section{Introduction}

The US airline industry began the year 2001 with 24 consecutive profitable quarters, and net profits in 2000 totaled $\$ 7.9$ billion. From 1990 through to the end of 2000, passenger travel volume rose at an average rate of $3.6 \%$ per year. Whereas the recession that began in the first quarter of 2001 signaled the end of profitability, the 9/11 terrorist attacks pushed the industry into financial crisis. Net reductions in profits totaled $\$ 3.2$ billion in the third quarter of 2001 , and $\$ 4.4$ billion for all of $2001 .{ }^{1}$ Indeed, these losses would have been significantly higher had the Congress not quickly passed the Air Transportation Safety and Stabilization Act in September 2001, which provided $\$ 5$ billion in emergency assistance to the airlines.

To understand the magnitude of the impact on passenger air travel, we evaluate recent trends in travel volume. Figure 1 shows the revenue passenger miles (RPM) for domestic air travel from 1989 to $2002 .^{2}$ As can be seen in the diagram, the impact on air travel volume was dramatic, with the volume of air travel down $31.6 \%$ in September 2001 compared to September 2000. The grounding of the fleet for three days in the wake of the attacks was followed by minimal travel activity during the latter half of the month. Over the September to December 2001 period, the decline was 20.2\% compared to the same period the previous year and the overall volume for 2001 finished below the 2000 levels by $12.1 \%$.

Even in light of the decline in domestic airline travel, an important question is whether the detrimental impact of the attacks was temporary or permanent. That is, has airline travel returned to the trend that existed prior to the terrorist attacks? There are reasons to believe that it has not. Economists have long viewed travel-mode choices as the outcome of a comparison of opportunity costs and benefits. Thus, anything that permanently raises the opportunity cost of travel, holding benefits constant, should reduce the optimal level of 
travel volume. Since the time cost of travel has risen as a consequence of additional airport security measures, this should reduce the likelihood of some trips by air. Hence, if these costs are now permanently higher, optimizing travellers will switch to other modes of travel for certain flights, especially those covering relatively short distances.

To determine whether air travel was permanently reduced, one must consider how the airline industry would have fared had the 9/11 attacks never occurred. That is, one must generate a counter-factual forecast of air travel volume in the absence of the terrorist attacks. This approach has been employed in a recent study to consider the impact of casino gambling on local employment growth. Specifically, Garrett (2004) develops forecasting models of employment growth for several counties in Illinois, Iowa, Mississippi and Missouri. He then generates predictions of the counter-factual employment growth in the absence of casino development. This forecast is then compared to the actual employment levels to derive the true impact of casinos on local employment. We take a similar approach in this study. After developing both econometric and time-series forecasting models of air travel volume using pre-9/11 data, we generate dynamic forecasts of air travel in the post-9/11 period. These data are then compared to actual air travel levels to determine the impact of the terrorist attacks.

The remainder of the paper is organized as follows. Section II develops the theoretical model, Section III develops the empirical models used to generate the counter-factual forecasts and presents the empirical findings. The final section contains concluding remarks.

\section{Theoretical model}

Moses and Williamson (1963) describe a modal choice model applied to commuting behaviour that focuses on the differential net income that can be earned from two alternative forms of commuting. ${ }^{3}$ We generalize this framework to consider the issue of intercity travel for either business or vacation travelers. Let us first consider the business traveler. Assume that an individual's net income $(Y)$ earned for the company is a function of the billable wage rate for the employees services $(w)$, the total time spent working $(e)$, and the out- 
of-pocket cost of travel $(c)$. The total time spent working $(e)$ is then equal to the stock of time $(s)$ minus the time spent traveling $(t)$ minus leisure time $(L)$. This gives a value of net income for air travel, $A$, as:

$$
Y_{A}=w^{*} e_{A}-c_{A}=w\left(s-L-t_{A}\right)-c_{A}
$$

Assume the stock of time is fixed at $s$, and the amount of leisure required by the worker is also a constant $\left(L_{0}\right)$ which gives:

$$
Y_{A}=w\left(s_{0}-L_{0}-t_{A}\right)-c_{A}
$$

for air travel, and

$$
Y_{C}=w^{*}\left(s_{0}-L_{0}-t_{\mathrm{C}}\right)-c_{\mathrm{C}}
$$

for travel by the alternative travel mode (e.g., travel by car). We then define the difference in net income resulting from these two alternative travel modes as:

$$
\mathrm{Z}=\mathrm{Y}_{\mathrm{A}}-\mathrm{Y}_{\mathrm{C}}=w^{*}\left(\mathrm{t}_{\mathrm{C}}-\mathrm{t}_{\mathrm{A}}\right)+\left(\mathrm{c}_{\mathrm{C}}-\mathrm{c}_{\mathrm{A}}\right)
$$

Equation 4 shows that the relative income depends on the relative difference in the implicit value of time spent traveling $\left(w^{*}\left(t_{C}-t_{A}\right)\right)$ and the difference in out of pocket travel expenses $\left(c_{C}-c_{A}\right)$. Assuming the implicit costs are solely a function of the wage (i.e. ignoring the disutility of time spent traveling), then air travel will be chosen if $Z$ is positive, and travel by car will be chosen if $Z$ is negative. If $Z$ is zero, the traveler be indifferent between the two alternative travel modes.

We can now evaluate the impact of the $9 / 11$ terrorist attacks (define the dummy variable $X=0$ in the pre-9/11 period and $X=1$ in the post $9 / 11$ period) on the choice of travel mode. The attacks resulted in an increase in the amount of time to travel by air $\left(\Delta \mathrm{t}_{\mathrm{A}} / \Delta \mathrm{X}>\right.$ $0)$, as new security measures were put in place. Simultaneously, the airlines dropped fares in an attempt to entice travelers to fly $\left(\Delta \mathrm{C}_{\mathrm{A}} / \Delta \mathrm{X}\right.$ $<0)$. Assuming that any changes in the volume of automobile traffic were insufficient to significantly change travel times $\left(t_{C}\right)$, the impact of the attacks on $Z$ are solely a function of the impacts on $t_{A}$ and $c_{A}$. This leaves the impact on $Z$ ambiguous since:

Applied Economics, Vol. 36, No. 4 (March 2006): pg. 363-370. DOI. This article is @ Taylor \& Francis (Routledge) and permission has been granted for this version to appear in e-Publications@Marquette. Taylor \& Francis (Routledge) does not grant permission for this article to be further copied/distributed or hosted elsewhere without the express permission from Taylor \& Francis (Routledge) 


$$
\Delta \mathrm{Z} / \Delta X=-w^{*}\left(\Delta t_{A} / \Delta X\right)-\Delta c_{A} / \Delta X
$$

If as a result of the 9/11 attacks, the increase in the monetary value of the implicit cost of time spent traveling $\left(-\mathrm{w}^{*}(\Delta \mathrm{t} A / \Delta \mathrm{X})\right)$ exceeds the lower out-of-pocket expense from the fare reductions $(-\Delta \mathrm{cA} / \Delta \mathrm{X})$ by a large enough margin (i.e. by a margin big enough to switch $Z$ from positive to negative), then travelers will switch from air travel to auto travel along that route. On the other hand, if the increment in travel times was small vis-á-vis the out-of-pocket cost reduction from lower fares, then $Z$ would increase which would increase the likelihood that a traveler would travel by air.

This analysis is too simplistic on at least one dimension. It incorrectly concludes that there is no disutility associated with travel via either mode of travel. Hence, changes in the implicit cost depended solely on changes in travel times, since the wage rate was assumed to be a constant, independent of travel mode. However, one can generalize the implicit value to depend not only on the monetary value of one's time, but also the disutility associated with the specific form of travel. Thus, redefining $\mathrm{w}$ as the monetized value of the disutility associated with travel, it is reasonable to expect that $w_{A} \neq w_{C}$, especially in the post-9/11 period. Thus, the difference in net income becomes:

$$
Z=Y_{A}-Y_{C}=w_{C} t_{C}-w_{A} t_{A}+\left(c_{C}-c_{A}\right)
$$

Re-evaluating the effect of the 9/11 event on the modal choice decision gives:

$$
\Delta Z / \Delta X=\Delta w_{A} / \Delta X^{\psi} t_{A}-w_{A}^{\psi}\left(\Delta t_{A} / \Delta X\right)-\Delta c_{A} / \Delta X
$$

From Equation $\underline{Z}$ it can be seen that the a priori sign expectation on $Z$ is still unknown, although the likelihood of $Z$ falling sufficiently to switch its' sign from positive to negative, increases since $\Delta \mathrm{w}_{\mathrm{A}} / \Delta \mathrm{X}>0$, and hence there are now two negative terms in the expression.

The model as described in Equation $\underline{6}$ easily generalizes to the modal choices of vacation travellers. It would not be surprising to find 
that the implicit value of time (i.e. $w_{A}, w_{C}$ ) differs from that of the business traveller for several reasons. First, the wage paid to the worker need not be the same as the billable hours to the employer. Second, leisure time is typically valued at a fraction of the wage paid to workers whereas time spent travelling for business would be valued at the full wage. Finally, one would expect any disutility associated with travel time to depend nonlinearly on the total amount of leisure time available for the pleasure trip (i.e., $\left.w_{A}\left(L_{\circ}\right), w_{C}\left(L_{\circ}\right)\right) .^{4}$ Nonetheless, even with these differences, the insights derived from Equation $\underline{7}$ remain intact.

Summarizing, we assume that the effects of the 9/11 attacks were to:

1. increase the travel time by air by more than they did the travel times for other forms of travel; ${ }^{5}$

2. reduce the out-of-pocket expenses for airline travel more substantially than they did for other forms of transportation;

3. increase the disutility associated with flying by more than they did for other forms of travel.

Based on these assumptions, we conclude that the impacts of the terrorist attacks on air travel are:

1. Theoretically ambiguous if the magnitudes of the various terms in Equation $\underline{7}$ are not established.

2. More likely to be detrimental to the decision to fly, the larger is $\left(-\Delta \mathrm{w}_{\mathrm{A}} / \Delta \mathrm{X} * \mathrm{t}_{\mathrm{A}}-\mathrm{w}_{\mathrm{A}}\left(\Delta \mathrm{t}_{\mathrm{A}} / \Delta \mathrm{X}\right)\right)$ vis-á-vis $(-\Delta \mathrm{cA} / \Delta \mathrm{X})$.

Thus, if fares eventually return to pre-9/11 levels, and if the disutility associated with flying also returns to pre-9/11 levels, the total volume of air travel will not return to its previous level so long as the additional security required increases the time necessary to fly. That is, some trips that once generated positive $Z$ values will now generate negative values, causing those travelers to switch to alternative forms of travel. 
NOT THE PUBLISHED VERSION; this is the author's final, peer-reviewed manuscript. The published version may be accessed by following the link in the citation at the bottom of the page.

\section{Empirical Model}

To test the impact of the 9/11 attacks on the US domestic passenger airline industry, we first develop two forecasting models. The models considered are a structural demand model, and a VAR model. For each model, dynamic ex-post forecasts are generated over a 16-month period prior to the attacks to test the forecast performance. These models are then re-estimated and dynamically forecast over the period 2001:09-2003:016 so as to project the path of sales, had the 9/11 attacks not taken place. The forecasts are compared with actual travel volumes over the period to ascertain whether the impact of the attacks appears to be temporary or permanent.

\section{Structural demand model}

There are a number of studies that investigate demand for air travel. For example, Battersby and Oczkowski (2001) examine domestic air travel in Australia, and include a number of determinants including the price, price of substitutes, income as proxied by industrial production and a seasonal demand dummy. In a study of charter air travel in Greece, Karlaftis and Papastavrou (1998) consider a similar set of determinants and also include a lagged dependent variable. Our structural demand model, which is given by Equation $\underline{8}$, builds off both of these earlier studies.

$$
\begin{aligned}
\mathrm{d}\left(\ln \left(R P M_{t}\right)\right)= & f\left(\mathrm{~d}\left(\ln \left(P_{R E A L t}\right)\right), \mathrm{d}\left(\ln \left(R P M_{t-1}\right)\right),\right. \\
& \mathrm{d}\left(\ln \left(P_{\text {REALSUBST } t-1}\right)\right), \mathrm{d}\left(U E_{t-1}\right), \\
& \left.\mathrm{d}\left(\ln \left(\text { Income }_{\text {MAf }-3}\right)\right), G W_{t, t}\right)
\end{aligned}
$$

We regress travel volume as measured by revenue passenger miles $(R P M)$ on the real price $\left(P_{R E A L}\right)$, lagged $R P M$, and numerous demand shifters. Among the demand shifters included in the model are the real price of substitute forms of travel as measured by the CPI for non-air travel divided by the general CPI ( $\left.P_{R E A L S U B S T}\right)$, the unemployment rate $(U E)$, personal income (Income), and three dummy variables for the months of the first Gulf War (GW). Both UE and Income are included to capture the transitory and more permanent aspects of economic activity on the demand for air travel, respectively. All variables used in

Applied Economics, Vol. 36, No. 4 (March 2006): pg. 363-370. DOI. This article is (C) Taylor \& Francis (Routledge) and permission has been granted for this version to appear in e-Publications@ Marquette. Taylor \& Francis (Routledge) does not grant permission for this article to be further copied/distributed or hosted elsewhere without the express permission from Taylor \& Francis (Routledge). 
the model, their data sources and their descriptive statistics are fully described in Table 1.

With the exception of the unemployment rate, and the Gulf War dummy variables, all remaining variables are measured in log form. A stationarity test (augmented Dickey-Fuller) on the dependent variable (revenue passenger miles) reveals that the series is non-stationary in levels, but stationary in the first difference. ${ }^{7}$ Thus, all continuous variables, with the exception of Income have been seasonal differenced to render them stationary, which expresses the model in growth form (year over year rates of change). Personal income is already in seasonally adjusted form, and thus seasonal differencing is not necessary. Since $P_{R E A L}$ is expected to be endogenously determined, Equation $\underline{8}$ is estimated using two-stage least squares, with lagged variables used as instruments. The regression findings are reported in Table 2.

The model explains approximately $53.3 \%$ of the variation in the differenced log of RPM. Moreover, all the coefficients have the anticipated sign when there is a sign prediction. As expected, the price and sales volume are inversely related to one another whereas the opposite is true for lagged income suggesting that air travel is a normal good. Growth rates in RPM decline with positive changes in the unemployment rate, but air travel does not appear to respond significantly to the real price of non-air travel. Finally, there was a significant decline in the growth of RPM in February and March of the first Gulf War, and the rate of change of RPM shows some persistence, as it is positively related to its one-month lag.

\section{VAR model}

A vector autoregression (VAR) model was estimated over the same time period as the structural demand model. The variables of the model $\left(\operatorname{In}(R P M), \ln \left(P_{R E A L}\right), \ln \left(P_{\text {REALSUBST }}\right), U E\right.$, and $\ln$ (Income $\left.)\right)$ were tested for the existence of cointegration using the method described by Pesaran et al. (2001). Following that procedure, an autoregressive distributed-lag (ARDL) model with no trend and an unrestricted intercept is estimated, and a joint test of significance was performed on the coefficients of the once-lagged variables listed above. The 
computed statistic is 2.27 , which falls below the lower bound of the test at the $5 \%$ level of significance, implying the variables are not part of a cointegrated system. Therefore, the once-lagged variables are removed from the model, resulting in a VAR-type equation, given by

$$
\begin{aligned}
& \mathrm{d}\left(\ln \left(R P M_{t}\right)\right)=f\left(\mathrm{~d}\left(\ln \left(R P M_{t-1}\right)\right), \mathrm{d}\left(\ln \left(R P M_{f-2}\right)\right),\right. \\
& \mathrm{d}\left(\ln \left(P_{R E A L_{3} t=1}\right)\right), \mathrm{d}\left(\ln \left(P_{R E A L, f=2}\right)\right) \text {, } \\
& \mathrm{d}\left(\ln \left(P_{\text {REALSUBST, } \mathrm{f}-1}\right)\right) \text {, } \\
& d\left(\ln \left(P_{R E A L S U B S T, t-2}\right)\right), d\left(U E_{t-1}\right) \text {. } \\
& d\left(\ln \left(\text { Income }_{M A_{p} t-3}\right)\right) \text {, } \\
& \left.\mathrm{d}\left(\ln \left(\text { Income }_{M A, t-4}\right)\right), G W_{t, t}\right)
\end{aligned}
$$

As indicated, the equation contains two lags of the stationary form of the variables used in the structural demand model (except for the unemployment rate) and includes dummy variables for the first Gulf War. The regression findings are reported in Table 3 . Similar to the structural demand model, there is evidence of persistence in the yearover-year growth of $R P M$. The sum of the coefficient estimates of $P_{R E A L}$ and $P_{R E A L S U B S T}$ are of the expected sign (negative, positive) and are significant with $p$-values of approximately 0.14 , similar to that of the unemployment rate. As was the case in the structural demand results, air travel can be considered a normal good, and the first Gulf War had some detrimental impact on the growth of airline travel.

\section{Ex-post forecasting}

The goal of the model development is to generate dynamic forecasts over the period 2001:09-2002:12 and then compare those counter-factual forecasts with the actual levels of RPM over that period. To test forecast accuracy, we re-estimate both models over a shortened time-period (1989:01-2000:04) and then dynamically forecast over the next 16 months leading up to September 2001 (i.e., 2000:05-2001:08). ${ }^{8}$ Both models do a good job of projecting the level of RPM over the 16 months immediately preceding the terrorist attacks. A plot of the actual level of RPM against the forecasts of the two alternative models is shown in Fig. 2.

For the structural model, the mean average prediction error (MAPE) was $1.2 \%$ and it was $2.1 \%$ for the VAR model. In addition, 
both models did a reasonable job of capturing directional accuracy (i.e. the predicted direction was correct for 12 of 16 months) as well as turning points in the data (i.e. it captured four of seven turning points). Both models also did a good job of predicting the variation in the data, as reflected in correlations between actual and predicted of $r=0.976$ for the VAR model, and $r=0.959$ for the structural model. There was no consistent evidence of bias in either model. The structural model under-predicted $R P M$ by an error of more than $1 \%$ in 5 of 16 months, and over-predicted air travel by an error in excess of $1 \%$ in 7 of 16 months. By comparison, the VAR model under-predicted RPM by an error of $1 \%$ or more just 2 of 16 months, and overpredicted air travel by more than $1 \%$ in 8 of 16 months. No individual error reached $5 \% .{ }^{9}$ Since both models perform reasonably, one may consider simply choosing one of the forecasting approaches. However, Bates and Granger (1969) suggest that even if one model is inferior in forecast performance, that a combination forecast may generate forecasts with lower standard errors than those of individual forecasts. To derive the weights for the individual forecasts, we employ a technique developed by Granger and Ramanathan (1984) in which the two models are estimated and in-sample fit values are derived for the Structural Demand $\left(f_{S D}\right)$ and VAR $\left(f_{V A R}\right)$ respectively. Linear regression is used to determine the forecast weights $\left(\beta_{1}, \beta_{2}\right)$, as shown in Equation $\underline{10}$.

$$
R P M_{t}=\beta_{0}+\beta_{1}^{*} f_{S D}+\beta_{2} f_{V A R}+u_{t}
$$

The regression findings are reported in Equation $\underline{11}$

$$
\begin{aligned}
R P M_{t}= & 0.174014+0.644731^{\text {w }} f_{S D}+0.349504^{\text {* }} f_{V A R} \\
& (1,196) \quad(2.421) \quad(4,460) \\
& R_{\text {ADI }}^{2}=0.997, \quad F=25222.63
\end{aligned}
$$

As can be seen, both weights are statistically significant, and a Wald test reveals that the sum of the weights is not significantly different from unity. Both the structural demand model and the VAR model are used to generate dynamic forecasts over the period 2001:09-2002:12, and then the joint forecasts are generated using Equation 11 . The exante forecasts are plotted against the actual RPM in Fig. 3 and the percentage error is reported in Table 4. 
Not surprisingly, the forecasting model substantially overpredicts actual RPM in the months immediately following the terrorist attacks given the dramatic decline in demand for air travel that only slowly ameliorated. The over-prediction is $54.1 \%$ in September 2001, and it steadily falls throughout the remainder of the year. The lowest level of over-prediction is $9.4 \%$ in March 2002. Over the period April 2002-August 2002, the model over-prediction is in the range of $12.8-$ $16 \%$. However, at the one year anniversary of the attacks, the level of over-prediction spikes to $24.4 \%$, and remains above $20 \%$ in October, increasing to nearly $31 \%$ in November ${ }^{10}$ before settling back into the 12\% range in December 2002.

One might be tempted to conclude that the over-prediction in the ex ante period is simply a continuation of the tendency found in the ex post testing of the model. While both the structural demand and the VAR models had a tendency to over-predict, the magnitude of over-prediction was minor. The MAPE was between $1.2 \%$ and $2.1 \%$ over the 16-month period immediately preceding the 9/11 attacks, and at no point did it exceed 5\%. In contrast, over the 16 months following the attacks, the MAPE was $21.3 \%$ and it never fell below $9 \%$.

\section{Conclusions}

It is clear that the 11 September 2001 terrorist attacks had a significant short-run impact on the domestic air travel industry, and several airlines were pushed to the brink of bankruptcy as a result of the reduced demand. Whereas the swift response of the Federal Government in September of 2001 averted a collapse of the industry, the research presented in this paper suggests that the detrimental impacts of the attacks were not temporary. Rather they are likely to persist. Such a finding is consistent with optimizing behaviour on the part of travellers, both business and pleasure, who experienced increased opportunity cost of travel. Thus, as long as the enhanced airport security measures necessitate earlier passenger arrival times than existed prior to the attacks, revenue passenger miles will be expected to remain below the levels that would have existed in the absence of $9 / 11$.

Applied Economics, Vol. 36, No. 4 (March 2006): pg. 363-370. DOI. This article is (C) Taylor \& Francis (Routledge) and permission has been granted for this version to appear in e-Publications@Marquette. Taylor \& Francis (Routledge) does not grant permission for this article to be further copied/distributed or hosted elsewhere without the express permission from Taylor \& Francis (Routledge). 
NOT THE PUBLISHED VERSION; this is the author's final, peer-reviewed manuscript. The published version may be accessed by following the link in the citation at the bottom of the page.

\section{Notes}

${ }^{1}$ Federal Aviation Administration, Aviation Policy and Plans, Aviation Industry Overview, FY 2000 and Aviation Industry Overview, FY 2001.

${ }^{2}$ Revenue passenger miles represent the product of the number of revenue paying passengers and the number of miles flown by those passengers. These data are derived from the Air Transport Association.

3 Moses and Williamson (1963) focused primarily on the choice between commuter rail versus automobile commuters, or alternatively the choice of route taken and tolls incurred for automobile commuters.

${ }^{4}$ One might argue that there is another important difference between business and pleasure travellers. That is, business travellers may be unconcerned with the out-of-pocket expenses associated with the trip assuming business travel is covered by the employer. However, this logic is flawed. We assume that it is the employer, rather than the traveller who makes the travel decision. The employer considers the full opportunity cost of travel when making the modal choice.

${ }^{5}$ We have compared air travel to automobile travel, yet it can be generalized to rail travel as well. The enhanced security measures for train travel did not increase the time necessary to travel by rail as much as they did for air travel.

${ }^{6}$ We eliminate the period beyond 2003:01 so as to avoid any confounding influence brought on by the US war in Iraq.

${ }^{7}$ The critical value of the ADF statistic for the revenue passenger miles, in level form is $t=2.88$, and the actual value is 0.984 , and hence we accept the null of a unit root. After first differencing, the value of the ADF is $t=5.13$ which exceeds the critical value of $t=2.88$. Given the strong seasonality in the data, we also test for stationarity in the seasonal difference. Again, we find that the revenue passenger miles series is stationary in the first seasonal difference (i.e. with no consecutive differencing).

8 The models were essentially unchanged when the estimation range was shortened with one exception. Although the income coefficient remained positively signed in the structural demand model, it became statistically insignificant.

${ }^{9}$ An ARIMA model of the year-over-year change of RPM was also estimated for 1989:01-2000:04 (with an AR term at lag 1 and MA term at lag 12) and ex post forecasts for 2000:05-2001:08 generated. They are in line with those reported above; the MAPE is $1.5 \%$, and that model over-predicts air travel by more than $1 \%$ nine times while it underpredicts RPM by more than $1 \%$ on just two occasions.

${ }^{10}$ Note that the substantial increase in over-prediction in November 2002 may reflect the fact that the Thanksgiving holiday weekend extends into

Applied Economics, Vol. 36, No. 4 (March 2006): pg. 363-370. DOI. This article is (C) Taylor \& Francis (Routledge) and permission has been granted for this version to appear in e-Publications@Marquette. Taylor \& Francis (Routledge) does not grant permission for this article to be further copied/distributed or hosted elsewhere without the express permission from Taylor \& Francis (Routledge). 
NOT THE PUBLISHED VERSION; this is the author's final, peer-reviewed manuscript. The published version may be accessed by following the link in the citation at the bottom of the page.

December 2002. This would be consistent with the finding of a much smaller over-prediction in December 2002. This pattern is also observed in earlier years where this phenomenon occurred.

\section{References}

Bates, J and Granger, CWJ. 1969. The combination of forecasts. Operational Research Quarterly, 20: 451-68.

Battersby, B and Oczkowski, E. 2001. An econometric analysis of the demand for domestic air travel in Australia. International Journal of Transport Economics, 28: 193-204.

Federal Aviation Administration. "Aviation Policy and Plans". In Aviation Industry Overview, FY 2000 and Aviation Industry Overview, FY 2001

Garrett, TA. 2004. Casino gambling and local employment trends. Federal Reserve Bank of St. Louis: Review, 86: 9-22.

Granger, CWJ and Ramanathan, R. 1984. Improved methods of combining forecasts. Journal of Forecasting, 3: 97-204.

Karlaftis, MG and Papastavrou, JD. 1998. Demand characteristics for charter air-travel. International Journal of Transport Economics, 25: 19-35.

Moses, LN and Williamson Jr, HF. 1963. Value of time, choice of mode, and the subsidy issue in urban transportation. Journal of Political Economy, 71: 247-64.

Pesaran, MH, Shin, Y and Smith, RJ. 2001. Bounds testing approaches to the analysis of level relationships. Journal of Applied Econometrics, 16: 289-326.

Wald, A. 1943. Tests of statistical hypotheses concerning several parameters when the number of observations is large. Transactions of the American Mathematical Association, 54: 426-82.

Fig. 1. Revenue passenger miles

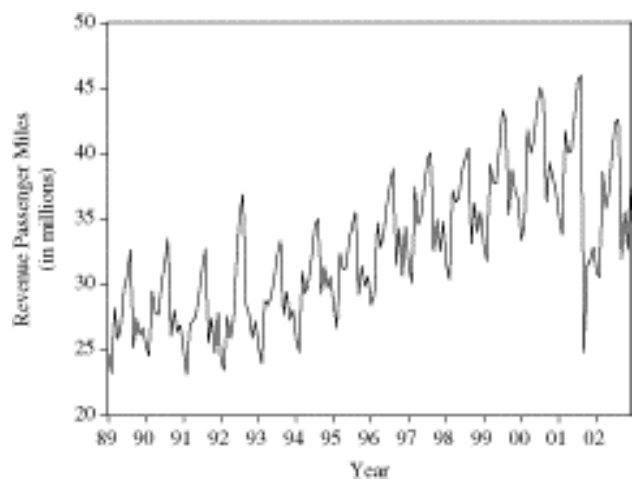

Applied Economics, Vol. 36, No. 4 (March 2006): pg. 363-370. DOI. This article is (C) Taylor \& Francis (Routledge) and permission has been granted for this version to appear in e-Publications@Marquette. Taylor \& Francis (Routledge) does not grant permission for this article to be further copied/distributed or hosted elsewhere without the express permission from Taylor \& Francis (Routledge) 
NOT THE PUBLISHED VERSION; this is the author's final, peer-reviewed manuscript. The published version may be accessed by following the link in the citation at the bottom of the page.

Fig. 2. Ex-post forecast performance (2000:04-2001:08)

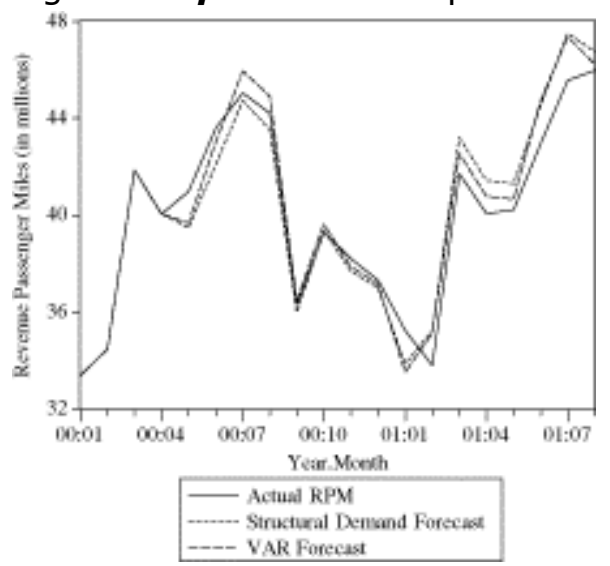

Fig. 3. Ex-ante forecast performance (2000:04-2001:08)

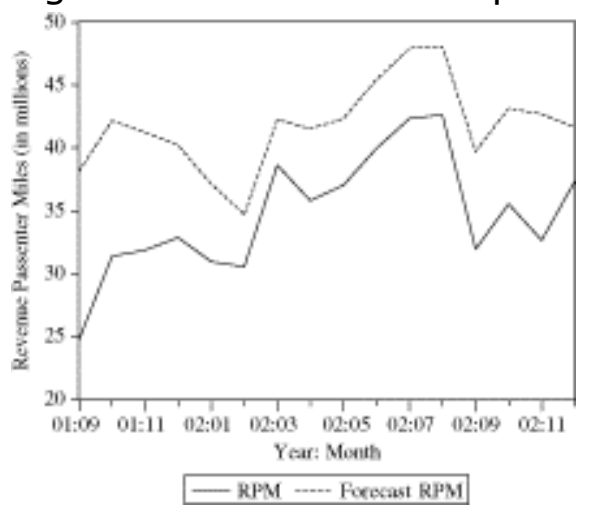

Applied Economics, Vol. 36, No. 4 (March 2006): pg. 363-370. DOI. This article is (c) Taylor \& Francis (Routledge) and permission has been granted for this version to appear in e-Publications@ Marquette. Taylor \& Francis (Routledge) does not grant permission for this article to be further copied/distributed or hosted elsewhere without the express permission from Taylor \& Francis (Routledge). 
NOT THE PUBLISHED VERSION; this is the author's final, peer-reviewed manuscript. The published version may be accessed by following the link in the citation at the bottom of the page.

Table 1: Variable Name and Definition, Data Source, Descriptive Statistics and Predicted Sign

\begin{tabular}{|c|c|c|c|}
\hline Variable name & $\begin{array}{l}\text { Definition [mean, standard deviation } \\
\text { for period 1989:01-2002:12] }\end{array}$ & Source & Predicted sign \\
\hline RPM & $\begin{array}{l}\text { Domestic Revenue passenger-miles are a measure } \\
\text { of the volume of air passenger transportation } \\
\text { by US carriers flying within the USA. A revenue } \\
\text { passenger-mile is equal to one paying passenger } \\
\text { carried one mile. (millions of miles) } \\
{[\mu=32.61, \sigma=5.40]}\end{array}$ & $\begin{array}{l}\text { Airline Transportation } \\
\text { Association }\end{array}$ & $\begin{array}{l}\text { Dependent } \\
\text { variable }\end{array}$ \\
\hline$P_{\text {REAl }}$ & $\begin{array}{l}\text { Monthly data reported to ATA by US majors } \\
\text { (excluding Southwest). The results are based on } \\
100 \text { percent of scheduled service and reflect } \\
\text { actual-full-fare, reduced-fare, and zero-fare-prices } \\
\text { (excluding taxes) paid by revenue passengers } \\
\text { based on } 1000 \text { miles of domestic travel divided } \\
\text { by the CPI ( } 1982-1984 \text { dollars) } \\
{[\mu=87.83, \sigma=10.90]}\end{array}$ & $\begin{array}{l}\text { Airline Transportation } \\
\text { Association }\end{array}$ & - \\
\hline $\mathrm{UE}$ & $\begin{array}{l}\text { Non-seasonably adjusted national unemployment } \\
\text { rate }[\mu=5.53, \sigma=1.08]\end{array}$ & $\begin{array}{l}\text { US Department of Labor, } \\
\text { Bureau of Labor Statistics }\end{array}$ & - \\
\hline$P_{\text {REALSUBST }}$ & $\begin{array}{l}\text { Transportation index not including air travel/CPI } \\
\quad(1982-1984=100)[\mu=1.00, \sigma=0.08]\end{array}$ & $\begin{array}{l}\text { US Department of Labor, } \\
\text { Bureau of Labor Statistics }\end{array}$ & - \\
\hline Income $_{\mathrm{MA}}$ & $\begin{array}{l}\text { Real Personal Disposable Income (billions of } \\
\text { chained } 2000 \text { dollars) }[\mu=5771.27, \sigma=684.24]\end{array}$ & $\begin{array}{l}\text { US Bureau of Economic } \\
\text { Analysis }\end{array}$ & + \\
\hline GULFWAR_JAN & $1=$ Gulf War in January 1991 & N/A & - \\
\hline GULFWAR_FEB & $1=$ Gulf War in February 1991 & $\mathrm{~N} / \mathrm{A}$ & - \\
\hline GULFWAR_MAR & $1=$ Gulf War in March 1991 & $\mathrm{~N} / \mathrm{A}$ & - \\
\hline
\end{tabular}

Table 2: Structural Demand Model of Revenue Passenger Miles 1989:012001:08

\begin{tabular}{|c|c|c|c|c|}
\hline Variable & Coefficient & Std. error & $t$-statistic & Prob.-value 2-tailed test \\
\hline \multicolumn{5}{|c|}{ Dependent variable: $\mathrm{d}(\ln ($ Revenue Passenger Miles $))$} \\
\hline Intercept & 1.037850 & 0.469948 & 2.208 & 0.0290 \\
\hline $\mathrm{d}\left(\ln \left(R P M_{t-1}\right)\right.$ & 0.508155 & 0.069100 & 7.354 & 0.0000 \\
\hline $\mathrm{d}\left(\ln \left(P_{R E A L, t}\right)\right)$ & -0.192243 & 0.065982 & -2.914 & 0.0042 \\
\hline $\mathrm{d}\left(\ln \left(P_{R E A L S U B S T, t-1}\right)\right)$ & 0.124976 & 0.123314 & 1.014 & 0.3127 \\
\hline $\mathrm{d}\left(U E_{t-1}\right)$ & -1.083575 & 0.486262 & -2.228 & 0.0276 \\
\hline $\mathrm{d}\left(\ln \left(\right.\right.$ Income $\left.\left._{M A, t-3}\right)\right)$ & 0.521442 & 0.302375 & 1.725 & 0.0870 \\
\hline Gulf War JANUARY $_{\text {JWA,t }}$ & -2.253767 & 2.981519 & -0.756 & 0.4511 \\
\hline Gulf War FEBRUARY & -5.371328 & 2.982505 & -1.801 & 0.0740 \\
\hline Gulf War MARCH & -5.577482 & 2.994740 & -1.862 & 0.0648 \\
\hline$R$-squared & 0.560250 & \multicolumn{2}{|c|}{ Mean dependent var } & 3.241960 \\
\hline Adjusted $R$-squared & 0.533188 & \multicolumn{2}{|c|}{ S.D. dependent var. } & 4.215671 \\
\hline S.E. of regression & 2.880299 & \multicolumn{2}{|c|}{ Sum squared resid. } & 1078.496 \\
\hline$F$-statistic & 18.60408 & \multicolumn{2}{|c|}{ Durbin-Watson stat. } & 2.074588 \\
\hline
\end{tabular}

Applied Economics, Vol. 36, No. 4 (March 2006): pg. 363-370. DOI. This article is (C) Taylor \& Francis (Routledge) and permission has been granted for this version to appear in e-Publications@Marquette. Taylor \& Francis (Routledge) does not grant permission for this article to be further copied/distributed or hosted elsewhere without the express permission from Taylor \& Francis (Routledge). 
NOT THE PUBLISHED VERSION; this is the author's final, peer-reviewed manuscript. The published version may be accessed by following the link in the citation at the bottom of the page.

Table 3: Vector Autoregression Model of Revenue Passenger Miles 1989:012001:08

\begin{tabular}{|c|c|c|c|c|}
\hline Variable & Coefficient & Std. error & $t$-statistic & Prob.-value 2-tailed test \\
\hline \multicolumn{5}{|c|}{ Dependent variable: $\mathrm{d}(\ln ($ Revenue passenger miles $))$} \\
\hline Intercept & 1.019970 & 0.503927 & 2.024 & 0.0451 \\
\hline $\mathrm{D}\left(\ln \left(R P M_{t-1}\right)\right.$ & 0.350468 & 0.092253 & 3.799 & 0.0002 \\
\hline $\mathrm{D}\left(\ln \left(R P M_{t-2}\right)\right.$ & 0.153061 & 0.094714 & 1.616 & 0.1086 \\
\hline $\mathrm{d}\left(\ln \left(P_{R E A L, t-1}\right)\right)$ & -0.340073 & 0.090920 & -3.740 & 0.0003 \\
\hline $\mathrm{d}\left(\ln \left(P_{R E A L, t-2}\right)\right)$ & 0.244297 & 0.095752 & 2.551 & 0.0119 \\
\hline $\mathrm{d}\left(\ln \left(P_{R E A L S U B S T, t-1}\right)\right)$ & -0.447755 & 0.277401 & -1.614 & 0.1090 \\
\hline $\mathrm{d}\left(\ln \left(P_{R E A L S U B S T, t-2}\right)\right)$ & 0.619771 & 0.273552 & 2.266 & 0.0252 \\
\hline $\mathrm{d}\left(U E_{t-1}\right)$ & -0.778299 & 0.521621 & -1.492 & 0.1382 \\
\hline $\mathrm{d}\left(\ln \left(\right.\right.$ Income $\left.\left._{M A, t-3}\right)\right)$ & 0.432113 & 0.320888 & 1.347 & 0.1805 \\
\hline $\mathrm{d}\left(\ln \left(\right.\right.$ Income $\left.\left._{M A, t-4}\right)\right)$ & 0.624177 & 0.325448 & 1.918 & 0.0574 \\
\hline Gulf War JANUARY & -2.367331 & 3.063965 & -0.773 & 0.4412 \\
\hline Gulf War FEBRUARY & -5.474754 & 3.081426 & -1.777 & 0.0781 \\
\hline Gulf War MARCH & -5.871944 & 3.084518 & -1.904 & 0.0593 \\
\hline$R$-squared & 0.559450 & \multicolumn{2}{|c|}{ Mean dependent var. } & 3.224544 \\
\hline Adjusted $R$-squared & 0.517158 & \multicolumn{2}{|c|}{ Akaike info criterion } & 5.081793 \\
\hline S.E. of regression & 2.936520 & \multicolumn{2}{|c|}{ Schwarz criterion } & 5.357549 \\
\hline Log likelihood & -337.6437 & \multicolumn{2}{|c|}{$F$-statistic } & 13.22804 \\
\hline Durbin-Watson stat. & 2.008419 & \multicolumn{2}{|c|}{ Prob. ( $F$-statistic $)$} & 0.000000 \\
\hline
\end{tabular}

Applied Economics, Vol. 36, No. 4 (March 2006): pg. 363-370. DOI. This article is (C) Taylor \& Francis (Routledge) and permission has been granted for this version to appear in e-Publications@Marquette. Taylor \& Francis (Routledge) does not grant permission for this article to be further copied/distributed or hosted elsewhere without the express permission from Taylor \& Francis (Routledge). 
Table 4. Actual versus forecast $R P M_{t}$

\begin{tabular}{|c|c|c|c|}
\hline Date & $\begin{array}{l}R P M_{t} \\
\text { (in millions) }\end{array}$ & $\begin{array}{l}\text { Forecast } \\
R P M_{t} \\
\text { (in millions) }\end{array}$ & $\begin{array}{l}\text { Percentage } \\
\text { error } \\
\text { (Actual- } \\
\text { Forecast) }\end{array}$ \\
\hline September 2001 & 24.73850 & 38.13142 & $-54.1 \%$ \\
\hline October 2001 & 31.38397 & 42.13238 & $-34.3 \%$ \\
\hline November 2001 & 31.85917 & 41.22065 & $-29.4 \%$ \\
\hline December 2001 & 32.84755 & 40.21690 & $-22.4 \%$ \\
\hline January 2002 & 30.95001 & 37.12695 & $-20.0 \%$ \\
\hline February 2002 & 30.53456 & 34.66465 & $-13.5 \%$ \\
\hline March 2002 & 38.61514 & 42.24493 & $-9.4 \%$ \\
\hline April 2002 & 35.79357 & 41.50472 & $-16.0 \%$ \\
\hline May 2002 & 37.02541 & 42.31917 & $-14.3 \%$ \\
\hline June 2002 & 39.95049 & 45.42108 & $-13.7 \%$ \\
\hline July 2002 & 42.33301 & 47.89873 & $-13.2 \%$ \\
\hline August 2002 & 42.62289 & 48.08896 & $-12.8 \%$ \\
\hline September 2002 & 31.93506 & 39.72110 & $-24.4 \%$ \\
\hline October 2002 & 35.53141 & 43.12760 & $-21.4 \%$ \\
\hline November 2002 & 32.65032 & 42.68623 & $-30.7 \%$ \\
\hline December 2002 & 37.30022 & 41.63548 & $-11.6 \%$ \\
\hline
\end{tabular}

Applied Economics, Vol. 36, No. 4 (March 2006): pg. 363-370. DOI. This article is @ Taylor \& Francis (Routledge) and permission has been granted for this version to appear in e-Publications@ Marquette. Taylor \& Francis (Routledge) does not grant permission for this article to be further copied/distributed or hosted elsewhere without the express permission from Taylor \& Francis (Routledge). 